\title{
CY-PRES IN THE SIXTIES: JUDICIAL ACTIVITY
}

\author{
L. SHERIDAN*
}

The conts have developed a beuvildering array of rules for determining the application of the cy-près doctrine. Professor Sheridan reviews and categorizes the recent decisions of American and Commonwealth jurisdictions and concludes that the doctrine is being applied in accordance with traditiounl principles.

Not very long after the late Professor Delany and I published our general treatment of the cy-près doctrine, ${ }^{\prime}$ a number of the reforms we recommended were enacted for England in the Charities Act, 1960, sections 13 and 14. Naturally, this diminished the value of our book to English lawyers (and to ourselves) and we brought out a supplement which not only explained the relevant provisions of the $1960 \mathrm{Act}^{2}$ (as far as we understood them ourselves), but also dealt with the cases reported up to 1st November, 1960. Since then, the English statute has been substantially adopted in the Republic of Ireland by the Charities Act, 1961, sections 47-48, and in Northern Ireland, by the Charities Act 1964, sections 22-3. The two Irish statutes go further than the English one in extending the discretion of the court by adding to the power of making cy-près schemes a power of making a scheme for the devotion to charity of property given on imperfect trusts: (i.e. trusts for mixed charitable and non-charitable purposes which, but for the statute, would be void), following the initiative of Victoria and other overseas common law jurisdictions. Meanwhile, cases have continued to come before the courts in unabated numbers in jurisdictions which have not enacted statutes. On the whole, these cases supply support for wellestablished doctrines, rather than providing any exciting new ideas.

\section{UNITED STATES DOUBTS}

Prerogative powers being shocking to a democratically minded people, courts in the United States of America have been torn between rejecting the cy-près doctrine, using it, and doing the same useful thing under another name ("deviation" or "approximation" or "nearness"), " where it has not been specifically introduced or confirmed by statute."

Arizona is one of the states refusing to embrace the cy-près doctrine. Yet it was held in Re Harber's Estate" that this did not prevent the court appointing a trustee so as to effectuate a charitable trust. Delaware

- Professor of Comparative Law. Queen's University of Belfast.

1 The Cy-Près Doctrine isweet \& Maxwell. 1959 I.

$\because$ And see B. J. Dovle, Reform in the Law of Cy-Prés (1964) 2 University of Tasmania Law Review 41. As to "reasonable" advcrtisentents under s. 1411)(a), see Re The Henry Wood National Memorial Trust, |1966) 1 W.L.R. 1601 (Stamp. J.).

$: 1961$ Act. s. 49: 1964 Act. s. 24. And sec L. A. Sheridon, Cy-Prés in the Cyxties: Imperfect Trusts (1966) 17 Northern Ireland Lesal Quarterly 235: M. C. Cullity. Statutory Salvage of imperfect Trust Provisions: An Exercise in Comparative Legislation (1967) 16 International and Comparative Law Quarterly 464.

+ Sce The Cy-Près Doctrine. at 18-19, 24-28: Sumplement, at 1: Report of the American Bar Association Committee on Charitable Trusts; J. T. Peters. A Decade of Cy-Pres 1955-1965 (1966) 39 Temple Law Quarterly 256; J. A. DiClerico. Cy-Prés: A Proposal for Change (1967), 47 Boston U.L. Rev. 153

- As to Alabama, where the doctrine was introduced by statute in 1940 . sec $\mathrm{L}$. U. Sims, Cy-Prés in Alabama (1964) 16 Alabama Law Reviow 428. As to Michiluan, see L. E. Blades. Historical and Theoretical Foundation for the Use of Cy-Prés in Michigan (1960) 39 Michigan State Bar Journal 13.

i) (1965) 409 P. $2 d ~ 31$ (judgment of the court by Stidham. J.). 
recognizes the cy-près doctrine.? New Jersey calls it the doctrine of approximation or nearness." In Ohio they call it the doctrine of deviation. In Fenn College v. Nance" Zybarger, J. applied it so as to allow a corporate college to transfer its premises and facilities to form a nucleus of the Cleveland State University, the corporation becoming a body for the support of educational, literary, charitable and scientific activities and projects. The learned judge referred to the "two doctrines" of cy-près and deviation in two paragraphs:

\begin{abstract}
$C y$-près means 'as nearly as may be'?" The doctrine is a simple rule of iudicial construction, designed to aid the court to ascertain and carry out, as nearly as may be, the intention of a donor of a gift to provide for the future. It is properly applied only where it is or has become impossible beneficially to apply the property left by the donor in the exact way in which he has dedicated it to be applied, and it can only be applied beneficially to similar purposes by different means.

Deviation is sanctioned by a court of equity to permit a departure from the terms of a trust where compliance is impossible or illegal, or where changed circumstances, not known or anticipated by a donor, would defeat or substantially impair the purposes of the trust.
\end{abstract}

In Virginia, in Smith v. Moore," Hoffman, C. J. left undecided whether the cy-press doctrine applied independently of legislation and held that it had been introduced retrospectively by statute so as to apply to this will. The Circuit Court of Appeals declined 12 to decide on the cy-près doctrine, but considered the allegedly separate doctrine of approximation. Winter. J., giving the judgment of the court, said: ${ }^{1:}$ "Aside from cy-près, which has application to charitable trusts, courts of equity, both in England and the United States, have long been recognized to have power in proper circumstances either to alter or to add to the literal terms of a private or charitable trust so that the broad intent of the settlor may be saved from frustration. A trust, whether private or charitable. will not be permitted to fail for want of a trustee. Similarly, the trust res may be sold or investments not authorized by the trust instrument may be made to preserve a trust threatened by changing external circumstances. And the exercise of such powers as those to which reference has been made has been sanctioned not only after a trust has become operative, but also to make operative a trust deficient in some regard at its inception. Thus, equity will authorize a trustee to designate beneficiaries or specific uses where the trust instrument is deficient in these respects. Equity may also direct literal compliance with the terms of a trust instrument. even though unforeseen circumstances, such as insufficiency of funds, prevent fulfillment on the scale obviously contemplated by the settlor.

"In a jurisdiction in which the doctrine of cy-près is fully recognized, courts often perform saving operations under its umbrella, but all of the results which have been described have also been accomplished without

7 Asche v. Asche (1964). 199 A. 2d 314 (Marvel, V. C.). For a California comment, sec C. A. Brigham. Modification of an Impracticable Charitable Trust (1965). 16 Hastings Law Journal 629.

- Montclair National Bonk and Trust Co. v. Seton Hall College of Medicine and Dentistry (1966), 217 A. 2d 897. 904 (Herbert. J.).

? (1965), 210 N.E. 2d 418.

11 And see Bonner v. Board of Trustees of the John M. Bonner Memorial Home (1966). 181 So. $2 \mathrm{~d} 255$ (judament of the Luisiann court delivered by Yarrut, J.): A. Weisberger. TB or not TB: Matter of Scott (1963), 19 New York University Intramural Law Review 28.

11 (1963). 225 F. Supp. 434

$12(1965), 343$ F. 2d 595 .

is 343 F. 2d 601-602. 
resort to cy-près. While equitable approximation is applicable to both private and charitable trusts, modern authorities suggest that the doctrine of equitable approximation is more extensive with respect to charitable trusts than to private trusts. This is not to say that the doctrine of equitable approximation is completely co-extensive with the doctrine of cy-près. However, the conclusion seems inescapable that in jurisdictions where the courts have rejected the doctrine of cy-près they have been more liberal in application of the doctrine of equitable approximation to save charitable trusts, so that the scope of the two doctrines has tended to merge. Indeed, the authorities are replete with references to the doctrines in the alternative, such as that of 'cy-près or equitable approximation' in instances where deviations from the strict terms of a charitable trust have been authorized, as if both terms described the same judicial power.

The Supreme Court of Appeals of Virginia has been in the forefront in giving broad scope to application of the doctrine of equitable approximation to charitable trusts. Wisconsin has rejected cy-près as such, but has arrived at the same result through a doctrine of 'liberal construction' enacted by statute." In Re Raulf's Estate ${ }^{15}$ there was a gift for unspecified charitable purposes. The court appointed a trustee to administer the property under their supervision. ${ }^{16}$

\section{INDIAN MORBIDITY}

Indian courts confine the cy-près doctrine to charitable gifts taking effect on death." This was probably the result originally of a misunderstanding of the English authorities, but it persists as Indian doctrine ${ }^{1 \times}$ and has been justified at length in Ravanna Koovanna Karuppannan Ambalam v. Vana Pana Tirumalai Ambalam'" by Ganapatia Pillai, J. (giving the joint judgment of himself and Venkataraman, J.) partly on the ground that the principle of giving effect to the donor's intention applies to wills but not deeds, partly on the ground that the donor by deed might be still alive and able to cope with the situation and partly on the ground that in India people do not give to charity by way of trust but by way of regarding the donee charity as a juristic person. What the relevance of all this is to the question of cy-près is unfathomable.

\section{CY-PRES AND PERPETUITY}

In Re Brier Estate," in British Columbia, there was an initial charitable gift which was conditional and was void for perpetuity. There was also a general charitable intent, but it was regarded as operating only in

14 See F. M. McBurney and D. F. Fuller, Restricted Scholarships: Problems in Standing to Challenge, Constitutionality. Cy Pres, and Legislative Policy (1963) Wisconsin Law Review 254, 313: L. J. Geronime, The $C y$ Pres Doctrine in Wisconsin (1965), 49 Marquette Law Review 387.

1. (1965). 137 N.W. 2d 416 (judgment of the court by Gordon, J.).

it And see Re Freshour (1959). 81 A.L.R. 2d 806.816 (Judgment of the Kansas Supreme Court Uy Schroeder. J.): Annotation, 81 A.L.R. 2d 819, 833-844. But cf. Mohanlal v. Habibuliah A.I.R. 1963 Patna 480, 485-486, per Ramratna Singh, J. (with whom Kanhaiya Singh. J. agreedl.

i: See The $C y$-Près Doctrine, at 24.

is Potti Swami \& Bros. v. Govindarajulu A.I.R. 1960 Andhra Pradesh 605, 611 (Hasan and Reddi. J. J.)

10 A.I.R. 1962 Madras 500. 503-504

21 (1959). 18 D.L.R. (2d) 670. And see A. J. McClean. Charitable Trusts, the Rule Against Perpetuities. Accumulation and $C y$-près (1963). I University of British Columbla Law Review 729, 755-758: R. J. Lynn. Perpetuities: The Duration of Charitable Trusts and Foundations (1966). 13 U.C.L.A. Law Review 1074, 1086-1092. 
relation to a time outside the perpetuity period. Ruttan, J. held that there could be no cy-près application. The learned judge said:" "It is true that a general charitable purpose is disclosed in the will, which would normally be sufficient to invoke the cy-près principle, but that general charitable purpose is only to govern if the specific gift to a particular charity has failed for a time well in excess of the perpetuity period. Cy-près cannot defeat the rule against perpetuities." In Jewish Home for the Aged of British Columbia v. Toronto General Trusts Corp.,"2 on appeal from affirmation by the Court of Appeal of Ruttan, J.'s decision, it was regarded as a gift subject to a condition precedent which might not happen within the perpetuity period, accompanied by an immediate general charitable intent, and the Supreme Court of Canada ordered cy-près application of the property.

A charitable gift is not void for perpetuity merely because it is possible that none of the property will be used during the perpetuity period, if the property is immediately given for charitable purposes.":i In A.-G. for South Australia v. Bray"t the whole fund was immediately devoted to charitable purposes but the trustees were empowered to postpone carrying them out until sufficient additional funds had been accumulated. The High Court of Australia held this to be no infringement of the rule against perpetuities.

\section{JURISDICTION}

Courts of equity are well used, since they act in personam, to making orders when a party's conscience is affected in relation to property abroad. A cy-près order can be (but rarely is) made in relation to a foreign charitable trust if the trustees are before the court.": If, however, the property is directed to be handed over to trustees abroad, this will be done, even though a scheme will eventually be necessary, without imposing a scheme on the foreign trustees."

In The Glasgow Magdelene Institution:" the Court of Session in Scotland considered the question of jurisdiction over a charitable institution incorporated by royal charter," coming to the conclusion that they could make a cy-près order in the circumstances that the Privy Council, not proposing to act itself, had no objection to the court doing so.

\section{THE NEED FOR CHARITY}

Legislation apart, courts have continued to insist that the cy-près doctrine has no application unless the primary gift which has failed is charitable, or would be charitable if effective.:" In Re Jenkins's Will Trusts $^{30}$ a gift for the abolition of vivisection by legislation, which is not

$\because 18$ D.L.R. (2d) 676-677.

2*: (1961), 28 D.L.R.(2d) 48.

2n See The Cy-Près Doctrine, at 101.

$\because 11964$ ), 111 C.L.R. 402.

2.. See Thie Cy-Près Doctrine, at 157-158.

in See Re Masoud (1961), 28 D.L.R. (2d) 646, where Wells, J.. in the Ontario High Court, so dealt with a gift for the education of chlldren in Syria.

$\because 1964$ S.C. 227 (Lord President Clyde and Lords Carmont, Guthrie and Migdale).

$\because$ See The Cy-Prés Doctrine, at 154.

:i" See The Cy-Près Doctrine, at 29-30.

i1) |1966| Ch. 249. And see'Schenerlein v. Schenerlein (1963), 197 N.E. 2d 231 (judgment of the Ohio court by France. J.): Olivas v. Board of National Missions of the Presbyterian Church, United States of America (1965). 405 P. 2d 481 (judgment of the Arizona court by Donofrio, J. ); Genetal Association of Davidian Seventh Day Adventists Inc. v. General Association of Davidian Seventh Day Adventists (1966). 410 S.W. 2d 256 (judgment of the Texas court by MeDonald, C. J.). 
charitable, was one of seven gifts, the other six of which were charitable. Buckley, J. refused cy-près application of the anti-vivisection gift. The learned judge said:" ". . . the principle of noscitur a sociis does not in my judgment entitle one to overlook self-evident facts. If you meet seven men with black hair and one with red hair you are not entitled to say that here are eight men with black hair." In MacTavish's Trustees v. St. Columba High Church:: Lord Johnston, in the Scottish Court of Session, applied the same principle to a gift to a non-existent institution. It was referred to in a list of fourteen institutions: the other thirteen were charitable but there was nothing (apart from the list) to show that the fourteenth, had it ever existed, would have been charitable, and cy-près application was refused.

\section{IMPOSSIBILITY OR IMPRACTICABILITY REQUIRED}

Prior to legislative relaxation, for example in England, a fairly strict requirement of impossibility or impracticability was imposed before property subject to a charitable trust could be applied cy-près::": There has been no relaxation of this requirement in countries without legislation." If it is impossible to carry out the purpose designated at the date when the gift takes effect, there must be an inquiry whether there is any reasonable prospect that it will become practicable. Only if the answer to that is in the negative will there be a true case of initial impossibility.

Partial impossibility will not provide a cy-près occasion." In In Edinburgh Corp. v. Cranston's Trustees"r there was a gift for twelve poor people fulfilling certain conditions. Only two were found. The Court of Session in Scotland held that the gift was operative so that there could not be a cy-près application nor was there any lapse.

Common instances of impossibility include a surplus in the funds after the designated purpose has been fully carried out;" and an institution named as recipient never having existed": or having ceased to exist before" or after" the gift takes effect. Another is illegality, including infringement of the rule against perpetuities. ${ }^{12}$ In Re Lushington,": it consisted of a direction to accumulate income for longer than the permitted period. In Tai Kien Luing v. Tye Poh Sun" Rigby, J., in Penang, held that a charitable trust to be carried out abroad in a

\footnotetext{
:1 Id. at 256 .

:: 1967 S.L.T. Notes 50.

:i: See The Cu-Pres Doctrine, at 31-32; Supplement, at 1

:1 See Re Sugrabai Mohainedai Alibhai Karimjee Charity Trust. |1960| E.A. 521 (Tanganyika. Mosdcll. J.): City of Worcester v. Directors of the Worcester Free Public Library (1965). 21i N.E. 2d 356 (judgment of the Massachusetts court by Spalding. J.): Destitute of Bennington County s. Henry W. Putman Memorial Hospital (1965). 215 A. 2d 134 (judament of the Vermont court by Kever. J.): Re Berry's Estate (1966). 139 N.W. 2 d 72 (judement of the Wisconsin court by Heffermin. J.): P. W. Blackman, Selected Problems of California Charitable Corporation Administration: Standing to Sue. and Directors' Ability to Change Purpose (1966) 13 U.C.L.A. Law Review 1123, 1127-1133.

:3 A.-G. for South A ustralia v. Bray (1964), 111 C.L.R. 402 (High Court of Australia). See The Cy-Pres Doctrine, at 155 .

: Estate Hofmeyr |1962! S.A. 314 (South Africa, de Vos, A. J.). See The Cy-Près Doctrine. at 31-32, 91-92; Supplement, at 1 .

a) 1960 S.C. 244.

is See p. post.

is See p. post.p. - 2

\II See p post.z... $z$

+1 See p. post.

t.2 See $p$. ante.

43 [1963] N.Z.L.R. 313. Ste The Cy-Près Doctrine, at 89 .

it (1960) 27 ML.J. 78.
} 
country with which the Federation of Malaya had no diplomatic relations was not impossible but that it would be illegal if exchange control permission was not given.

Yet another common source of fatality is that there is no need for the carrying out of the chosen purpose, sometimes as a result of circumstances having changed, for example, a gift for the paying of school fees is impossible in a place where education is free. ${ }^{4 s}$ In Parker v. Moseley ${ }^{4 h}$ a trust of land was set up in 1921 and in 1924 a small hall for local residents (in what was then a rural area) was built. By 1965 the area was urban and the hall, now little used, was in disrepair. The cost of repair would have been, in the words of the judge,"7 "out of all proportion to the usefulness of the hall and its capacity to provide income, especially in the light of the fact that in recent years the hall has increasingly become the target of marauding vandals." To provide an adequate modern hall would have cost at least $£ 20,000$-much beyond the trust's funds. The learned judge held that the trust was charitable and that a general charitable intent existed, but counsel for the AttorneyGeneral contended that the original purposes were still capable of being carried out. Starke, J. held" that "due to the lapse of time and change of circumstances, it is no longer possible beneficially to apply the property in the exact way that the donors directed it to be applied." He further said: ": ". . . an insistence that the precise directions of the original trust be complied with . . . would obviously defeat [the original donors'] express intention, for they would be providing a hall which is useless for the purposes of the community which it is supposed to serve." So he held the original directions impossible and made a cy-près order.

A bequest of too little for a purpose may also be a variety of impossibility or impracticability,:0 but this will not be the case if the donor expects someone else to supplement it and that supplementation may occur: Connecticut College v. United States." In that case, Miller, J., in giving the judgment of the majority of the Circuit Court, said: 12

A provision of a charitable trust may be changed by a court of equity if its performance has become impossible or impracticable through changed conditions and circumstances over which the trustee and the beneficiary have no control. But the cy-près doctrine does not authorize or permit a court to vary the terms of $a$ bequest and to that extent defeat the intention of the testator merely because the variation will meet the desire and suit the convenience of the trustee. ... Nor may a trustee by his own act produce changed conditions which frustrate the donor's intention and still claim the gift through the application of the cy-près doctrine.

In this case the site designated by the donor for the carrying out of his purpose belonged to the trustee (defendant). The site was suitable for the donor's purpose but was reserved by the donee for something else. The majority held that there was no impossibility and therefore no cy-près application was ordered nor did the gift over to residue take effect.

4i Re Mackenzic. |1962| I W.L.R. 880 (Pennycuick, J.): Re Peacock's Charity, |1956) Tas. S.R. 142 (Tasmania. Giuson. J.). See The Cy-Près Doctrine, at 91. to |1965| V.R. 580 (Victoria).

$+7|1965|$ V.R. 582 .

A. 1965 V.R. 584 .

+H I965 V.R. 585

ini See The Cy-Pres Doctrine, at 86-87.

il (1960), 276 F. 2d 491 (District of Columbia).

s: 276 F. 2d 497 . 
The refusal of the trustee to carry out the precise terms of the gift while willing to perform the main function may be more kindly looked upon, though, when the terms objected to by the trustee detract from the main purpose of the gift, as where a donee is an educational establishment objecting to a clause discriminating on non-educational grounds against classes of potential beneficiaries. In Howard Savings Institute v. Amherst College "deserving American born, Protestant, Gentile, boys of good moral repute, not given to gambling, smoking, drinking or similar acts. (It being my thought that if a young man has enough funds to allow the waste of smoking, he certainly does not need help.)" The college, which was non-sectarian, refused the bequest if the scholarship was to remain restricted to Protestants and Gentiles (apparently they did not object to the restrictions as to place of birth and moral reputation). Section 6 of the college charter provided: ". . . no student shall be refused admission to, or denied any of the privileges, honors, or degrees of said College, on account of the religious opinions he may entertain." The Superior Court of New Jersey applied the bequest cy-près to the college by striking out "Protestant" and "Gentile," on the grounds that the next-of-kin were remote, the residuary gift was on the same trusts, there was no gift over and that the testator's primary regard was for the college rather than the conditions.

In Re Lysaght" Buckley, J. had to deal with a similar situation and arrived at a similar result. The testatrix gave money to the Royal College of Surgeons of England for studentships but prescribed that "any such student must be a British born subject and not of the Jewish or Roman Catholic faith." The College declined to take the gift with the religious discrimination still there (but did not object to the nationality restriction) because, so they said, the exclusion of Catholics and Jews was "so invidious and so alien to the spirit of the college's work as to make the gift inoperative in that form." The learned judge rejected the contention that the exclusion was void for uncertainty and also, though accepting that the discrimination was undesirable, rejected the contention that it was contrary to public policy. The case also differs from the Amherst College case in that the College of Surgeons was not restrained by its constitution from operating religious discrimination. The learned judge also accepted that the terms of a trust could not be modified merely because they conflicted with the opinions of the trustee. But he came to the conclusion that it was vital to the testatrix that the college should be the trustee and that impracticability of a minor condition (religious discrimination) must not be allowed to defeat the paramount intention (medical studentships administered by the college). He ordered cy-près application and found support in Re Robinson.:s

The racially discriminatory charitable trust ${ }^{5 i}$ has attracted much recent attention in the United States of America. In Evans v. Newton:77 the majority of the Supreme Court removed the colour restriction from a

An (1960), 160 A, 2d 177. See The Cy-Près Doctrine, at 89-90, 92-93.

it $|1966|$ Ch. 191 .

6i $|1923| 2$ Ch. 332. See The Cy-Prés Doctrine, at 89-90; F. H. Newark's note (1966). 17 Northern Ireland Legal Quarterly 123.

5.: See The Cy-Près Doctrine, at 89, n. 65.

37 (1966), 382 U.S. 296. 
devise of land in Georgia to be used as a park and pleasure ground for white people only. This, however, was on the basis that it was unconstitutional, offending the Fourteenth Amendment, because the devise was to a public body, the City of Macon corporation, and because a park, even if privately owned, "is municipal in nature." ix A park is "like a fire department or police department that traditionally serves the community. Mass recreation through the use of parks is plainly in the public domain .... and state courts that aid private parties to perform that public function on a segregated basis implicate the State in conduct proscribed by the Fourteenth Amendment." One should, no doubt, refrain from sniffing at a decision that goes a long way in the right direction merely because it does not go all the way. The Supreme Court will, it is to be hoped, detect a public element in cases of racial discrimination even though the public element may escape the notice of less discerning people, but there will still be a private sector left untouched by constitutional law."it In countries without entrenched constitutional provisions governing the matter, racial discrimination in charitable trusts is left to be dealt with by ordinary legislation or, failing that, the judicial development of rules based on equitable principles. The two weapons to hand are: (a) that the discrimination is illegal as contrary to public policy (not so far used); (b) that the discrimination is an inessential detail which conflicts with a more general paramount intention.

\section{INITIAL AND SUPERVENING IMPOSSIBILITY:}

\section{NATURE OF THE DISTINCTION}

Where a charitable object is impossible at the date of the gift there is said to be a case of initial impossibility; where the impossibility arrives after the date of the charitable gift there is said to be supervening impossibility. The importance of the distinction is that in cases of initial impossibility there will be cy-près application only if the donor had a general charitable intent while in cases of supervening impossibility there will be cy-près application provided there is no alternative disposition of the property directed to take effect on the impossibility supervening. ${ }^{n}{ }^{1}$

In Beggs v. Kirkpatrick,": Adam, J. said: ". . . where the fund may be considered to have once vested in charity, or been effectively dedicated to charity, there is strong authority for the view that the court has jurisdiction to direct an application cy-près of funds belonging to that charity and that it is irrelevant to consider whether donations to it had been made originally for a specific purpose only, or with some more general charitable intention ... In the ... case [where the purpose has altogether failed to take effect], ... whether by reason of

sx 382 U.S. 301, per Douglas, J., giving the opinion of the majority.

s!l Per Douglas, J., 382 U.S. 302.

iil And see E. H. Abbott. Supreme Court and the Girard Will Case (1960) 21 Alabama Lawyer 227; R. W. Power. The Racially Discriminatory Charitable Trust:A Suggested Treatment (1965) 9 St. Louis University Law Journal 478: L. M. Mullen. Constitutional Law-Judicial Enforcement of the Racially Discriminatury Charitable Trust (1966) 10

St. Louis U.L.J. 576; R. S. Lingo, Trusts-State Action in Charitable Trusts (1966) 45 Nebraska Law Review 826 . (Notej, Constitutional Law: Applicability of the Fourteenth Amendment to a Charitable Trust in thich a State Agency Was the Orivinal Trustee (1966) 19 Vanderbilt Law Review 939; E. McComas. Trusts: Application of Cy Pres to Remove Discriminatory Racial, and Religious Restrictions from a Charitable Trust (1967) 20 Oklahoma Law Review 101.

(i) See The Cy-Pres Doctrine, at 37-39, 99-103; Supplement, 4

02 [1961] V.R. 764, 767 (Victoria). 
impracticability or otherwise, the trust is considered to have failed $a b$ initio. As the law now stands, the consequence of such a trust failing $a b$ initio is that subject to one qualification referred to hereafter, the funds must be returned to the donors unless it appears that the accomplishment of the particular purpose did not exhaust the charitable intention of the donor, and that his substantial intention was to advance some wider charitable purpose, although by means of the particular purpose. In such a case, the circumstance that the trust for a particular purpose is incapable of literal execution according to its tenor is not fatal to the gift which may then be administered cy-près by a Court of Equity. There are instances of a donor having, as is said, manifested a 'general charitable intention'-an expression used to describe a charitable intention wider than the advancement of the particular purpose which has failed, although not necessarily 'general' as that word is commonly used. As a qualification upon this statement it appears that without there being any general charitable intention, a gift made solely for a particular charitable purpose, although it has failed $a b$ initio, will be administered cy-près if the gift was an out and out gift-the donor having abandoned all interest in it-and the Attorney-General has waived the claim of bona vacantia and by bringing in a scheme or otherwise has consented to its application for some other charitable purpose." The learned judge took the view that there was no general charitable intent just because the gift to charity was out and out. Nor was a gift from an identifiable donor affected in this respect by the existence (to his knowledge) of anonymous donors to the same fund. ${ }^{63}$ The facts of this case were similar to those in Re Ulverston and District New Hospital Building Trusts"1-it being impossible to build a new hospital with the fund subscribed-and a somewhat similar result was arrived at. Adam, J. treated the case as one of initial impossibility and, there being no general charitable intent, ordered the return of subscriptions to the donors except the anonymous ones. As to these, the Crown having waived its rights in bona vacantia, the learned judge held that the trustees could apply the donations to a new purpose: enlarging an old hospital instead of building a new one.

Where a fund is subscribed for a lawful purpose which eventually cannot be carried out, for example because the total collected is too low or because the purpose becomes unnecessary or illegal, the case would in fact appear to be one of supervening impossibility because the charitable trust attaches immediately to the sums as subscribed. The alternative of viewing the case as one of initial impossibility seems to necessitate regarding all subscriptions as conditional on it being possible on some future date to carry out the purpose and, if carried to its logical conclusion, seems to result in all charitable collections being void for perpetuity except in jurisdictions which have enacted "wait and see" or some other modification of the rule against perpetuities.

\section{OTHER INITIAL IMPOSSIBILITY CASES}

Subject to the qualification expressed by Adams, J. in Beggs v. Kirkpatrick $^{\mathrm{us}}$ as to anonymous donations disclaimed by the Crown, in 
cases of initial impossibility, if there is no general charitable intent, there can be no cy-près order and the property intended for charitable purposes will go under the gift over (if any), on a resulting trust, or as bona vacantia, as the case may be. ${ }^{\circ i}$ If, on the other hand there is a general charitable intent, there will be a cy-près order.:"

A general charitable intent is one, no matter how narrow, wide enough to embrace the impossible purpose (or detail) and at least one other (possible) purpose (or absence of the impossible detail). ${ }^{1: x}$

In Re Peacock's Estate, ,: where it was unnecessary to find a general charitable intent because it was a case of supervening impossibility, Gibson, $\mathbf{J}$. based his finding of such an intent on the following clause in a will:

And in the event of the said Government of Tasmania not accepting the devise of my residence upon the conditions hereinbefore provided then I devise my residence and my residuary real and personal estate to my trustees to be held by them upon such charitable trusts as the Supreme Court of Tasmania by the operation of the cy-près doctrine shall decide as best effectuating my intention and wishes with regard to my residence and my residuary real and personal estate.

Who can say fairer than that? Possibly one might have decided that if an intention that the cy-près doctrine should be applied had been expressed there was no need to ask any other questions.

In Rhode Island Association for the Blind v. Nugent, ${ }^{70}$ where a gift failed in so far as it was to a particular organization, Powers, J. held that there was a general charitable intent (that is, that the purpose rather than the organization was paramount) because two charitable gifts were coupled in the same devise and because the testatrix had had an interest in and had made charitable gifts inter vivos."

In $R e$ Lushington, $i:$ where a direction to accumulate funds to establish a park was held void for excessive duration, Woodhouse, J. found a general charitable intent to be lacking in this way:

It is true that all the inhabitants of the area surrounding the proposed park are the ultimate beneficiaries, and the gift will be of general benefit to the district, but the fact does not enable me to ignore what seems to be the clear intention of the testatrix as disclosed by the will. The opening words of cl. 11 show in plain terms that her intention was directed to a defined area of land and it was this property that she wished to have dedicated as a public park. In order to apply the cy-pres doctrine it would be necessary to spell out of this a general intention on the part of the testatrix to set up a charity of this general nature, and that she had chosen this particular form of gift in order to give expression to it. But I am unable to reach this conclusion. In my opinion her predominant

(ii) La Fond v. City of Detroit (1959). 98 N.W. 2d 530 (Michigan): Tai Kien Luing v. Tye Poh Sun (1960), 27 M.L.J. 78 (Penang); Beggs v. Kirkpatrick, $\{1961 \mid$ V.R. 764 (Victoria): McRobert's Trustees v. Cameron 1961 S.L.T. Notes 66 (Scotland): Re Lushington, [1963] N.Z.L.R. 313 (New Zealand): Re Berry's Estate (1966). 139 N.W. $2 d 72$, where the wisconsin court held that, a charity having refused a gift, there could be no cy-pres application in defiance of express provision (here. a gift over) for that eventuality. See The Cy-Pres Doctrine, at 77-84; Supplement, 3.

it Jewish Home for the Aged of British Columbin v. Toronto General Trusts Corp., [1961] S.C.R. 465 (Canada): Re Armour (1963). 38 D.L.R. (2d) 204 (Saskatchewan): Ex parte Estate Impey. |1963| i S.A. 740 (South Africa): Rogers v. A.-G. (1964): 196 N.E. 2d 855 (Massachusetts): Re Blaxland, |1964-5) N.S.W.R. 124 iNew South Wales): Re Lysaght, $|1966| \mathrm{Ch}$. 191. See The Cy-Près Doctrine, at 74-76; Supplement, 3. in See The Cy-Pres Doctrine, at 33-36; Supplement, at 1.

(i) [1956] Tas. S.R. 142 (Tasmania).

i1 (1965), 206 A. 2d 527, 530 (Rhode Island).

-1 Other explanations of the rature of a general charitable intent are to be found in Begos v. Kirkpatrick [1961] V.R. 764. 767 (Victoria. Adam, J.) quoted n. 62. supra: Re Lysaght, |1966| Ch. 191. 201-203 (Buckley, J.): Montclair National Bank and Trust Co. v. Seton Hall College of Medicine and Dentistry (1966), 217 A. 2d 897, 904 (New Jersey, Herbert. J.).

72 [1963] N.Z.L.R. 313, 319 (New Zealand). 
purpose was to set up and endow this particular area as a park and recreation ground ...

So, there being no general charitable intent, there was no cy-près order.

One type of initial impossibility where it is particularly easy to show a general charitable intent is that where a testator has given property to a named institution which has never existed. ${ }^{73}$ If the donor has not even bothered to find out whether there is any such institution, the inference is clear that its assumed purposes were more important than the identity of the organization carrying them out."i In MacTavish's Trustees v. St. Columba High Churchi: there is a rare example of such a gift failing. That was because there was nothing to show that the objects of the institution named would have been charitable had it existed. In the same case Lord Johnston ordered cy-près application of another gift to a fictitious institution.

On the other hand, if a testator leaves property to a named institution which has existed but no longer exists at the date of his death, a general charitable intent is harder to prove because there is no inference to be drawn one way or the other from the expiry of the institution." If the true construction of the will is that the purposes were more important to the testator than the particular organization there will be a cy-près order, "i but if the organization is made by the will to be an essential part of the gift the legacy will lapse. ${ }^{78}$

\section{OTHER SUPERVENING IMPOSSIBILITY CASES}

The principle is that, "Cy-près is available on subsequent failure unless a charitable gift is shown to be determinable."79 If a gift is given out and out to charity, the gift takes effect, and impossibility supervenes, there will be cy-près application without any inquiry as to general charitable intent." ${ }^{k 11}$ Occasionally courts require a general charitable intent and find it. ${ }^{\mathrm{R}}$ In Re Peacock's Charity ${ }^{\mathrm{s} 2}$ there was a devise of a house with an endowment for a convalescent hospital for patients leaving

i3 See The Cy-Près Doctrine, at 104-107; Supplement, 4.

74 EI parte Blum [1964] 2 S.A. 643 (South Africa. Corbett. J.): Re MurTay, [1964-5] N.S.W.R. 121 (New South Wales, Hardie, J.); Re Satterthwaite's Will Trusts, [1966] 1 W.L.R. 277 (Court of Appeal): Pomphrey's Trustees v. Royal Naval Benevolent Trust, (1967) S.L.T. 61 (Scottand, Lord Fraser); Cumming's Executors v. Cumming. (1967) S.L.T. 68 (Lord Fraser).

is [1967] S.L.T. Notes 50 (Scotland). Cf. Re Satterthwaite's Will Trusts, [1966] 1 W.L.R. 277.

7it See The Cy-Près Doctrine, at 108-112; Supplement, 5.

77 Re Quesnel, [1959] S.A.S.R. 106 (South Australia, Napler, J.); Re Roberts, [1963] 1 W.L.R. 406 (Wilberforce, J.); Rhode Island Assoctation for the Blind $v$. Nugent (1965), 206 A. 2d 527 (Rhode Island, Powers, J.): Re Satterthwaite's Whil Trusts. 1866 1 1 W.L.R. 277 (Court of Appeal)

is Re Quesnel, [1959| S.A.S.R. 106 (South Australla, Napier, J.):

Re Fisher, 11959) O.W.N. 46 (Ontario, Schatz. J.):

Re Allendorf (1963), 38 D.L.R. (2d) 459 (Ontario, Schatz, J.):

Re Slatter's Will Trusts, 1964] Ch. 512 (Plowman, J.).

io J. D. Davies. Evading Charity Reform: A Re-examination of Determinable Charitable Gifts (1961), 25 Conveyancer and Property Lawyer N.S., 56, 70. See The Cy-Près Doctrine, at 94-103; Supplement, 4. But in Vadivelu Mudaliar v. Rajabuda Mudaliar A.I.R. 1967 Madras 175, obiter, it was sald that a general charitable intent was necessary.

so Clutterbuck, [1961] S.L.T. 427 (Scotland, Lord President Clyde and Lords Carmont, Sorn and Guthrie): Re The Lord Mayor of Belfast's Air Raid Distress Fund, [1962] N.I. 161. 167 (Northern Ireland, MeVeigh, J.): Re Gordon (1965), 52 D.L.R. (2d) 197 (Ontario, Ferguson, J.). where, however, there was no supervening impossibllity: just a change of name of an institution; Parker v. Moseley, [1965) V.R. 580 (Victoria, Starke, J.): Fenn College v. Nance (1965), 210 N.E. 2d 418 (Ohio, Zybarger. J.): A.-G. for New South Wales v. Perpetual Trustee Co. Ltd. (1966), 40 A.L.J.R. 97 (High Court of Australia), where the distinction between Initial and supervening impossibility was considered: Trevathan v. Ringgold-Nolan Foundation Inc. (1967), $410 \mathrm{~S} . \mathrm{W} .2 \mathrm{~d} 132$ (Judgment of the majority of the Arkansas court delivered by Jones, J.): 81 Cf. Tai Kien Luing v. Tue Poh Sun (1960), 27 M.L.J. 78 (Penang, Rigby, J.).

82 [1956] Tas. S.R. 142 (Tasmania). See supra, at n. 59. 
public hospitals. A diminution later took place in the number of these patients, so it was proposed to admit persons discharged from private hospitals. Gibson, J. held that impossibility had supervened, that it was necessary to look for a general charitable intent, that such a thing could be found, and that the cy-près order would be made as asked.

If the gift was not originally made out and out to charity, on it becoming impossible to carry on with the donor's purpose effect must be given to the determinability of the gift (by resulting trust or gift over) unless there is an unfulfilled general charitable intent. From Ex parte McDonald's Club ${ }^{* 3}$ it seems that the court will not make a cy-près application if there is a gift over to another charity, but nothing was said in that case about a general intent in relation to the charity that had become impossible.

Surplus in the fund after totally carrying out the designatd charitable purpose is one variety of supervening impossibility.st Allied to this is the windfall. In $R e$ Burns ". an accumulation was directed by way of prior limitation, with remainder to charities. The accumulation was ended by the statutory limitation before the date specified by the testator and it was held that (there being a general charitable intention) the extra income went then to the charities.

The dissolution or cessation of functioning of a charitable corporation or unincorporated association, also, gives rise to application of the orthodox principles governing supervening impossibility. ${ }^{\text {s" }}$

On dissolution of a charitable corporation, unless there is some express provision otherwise, the assets go in accordance with a cy-près

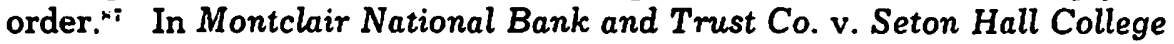
of Medicine and Dentistry" there was a gift by will to a charitable corporation. Shortly after the testator died, the charitable activity was taken over by a new corporation. The old corporation still existed and had debts. Herbert, J. held that the legacy must go to the new corporation for the charitable work, not to the old corporation for its creditors. The learned judge's opinion was that a gift to an institution without any elaboration should be regarded as a gift for its purposes. There being a case of supervening impossibility, there was a cy-près application on the footing that a general charitable intent was present, but the learned judge also thought that such an intent should not be necessary to give rise to the jurisdiction. In Re Armour, ${ }^{\text {,9 }}$ where a charitable body was taken over as a government agency, MacPherson, J. applied the charity property cy-près to the government agency.

R3 [1961] 2 S.A. 728 (Southern Rhodesia, Young. J.).

N4 See The Cy-Près Doctrine, at 115-128: Supplement, 5: Vadivelu Mudaliar v. Rajabada Mudaliar A.I.R. 1967 Madras 175; J. D. Davies. Evading Charity Reform: A Reexamination of Determinable Charitable Gifts (1961) 25 Conveyancer and Property Lawyer N.S. 56.

м. (1960), 25 D.L.R. (2d) 427 (Alberta Supreme Court Appellate Division).

8o Sec The $C y$-Près Doctrine, at 112-114: Supplement, p. 5: M. A. Hickling. The Destination of the Funds of befunct Voluntary Associations (1966) 30 Conveyancer and Property Lawyer N.S. 117: N. H. Alford. The Disposition of Assets Upon Failure of a Charitable Trust or Corporation: Policy Relationship to Enforcement of Charities (1964), 9 Utah Law Review 217.

$*$ Stevens Bros. Foundation Inc. v. Commissioner of Internal Revenue (1963). 324 F. 2d 633 (Delaware. Judgment of the Elghth Circuit Court of Appeals by Matthes. J.).

8s (1966), 217 A. 2d 897 (New Jersey).

80 (1963). 38 D.L.R. (2d) 204 (Saskatchewan). And see Rhode Island Association for the Blind v. Nugent (1965), 206 A. 2d 527. 


\section{CONCLUSION}

Case law has remained profuse but has not broken new ground. Developments in the law of judicial discretion over charitable trusts have been legislative. In countries not enacting new legislation the cases comprise occasional clarification of traditional doctrine, occasional novelty of illustration, occasional difficulty in application and abundant repetition. 